\title{
Solutions of the Roller Conveyor in Terms of Logistics Provider
}

\author{
Lucia Madleňáková1*, Mária Matúšková1, Radovan Madleňák', \\ Anna Rudawska², Iwona Rybicka² \\ 1 University of Žilina, Faculty of Operation and Economics of Transport and Communications, Univerzitna 1, \\ 010 26, Žilina, Slovakia \\ ${ }^{2}$ Lublin University of Technology, Faculty of Mechanical Engineering, Nadbystrzycka 36, 20-618 Lublin, Poland \\ * Corresponding author's e-mail: lucia.madlenakova@fpedas.uniza...sk
}

\begin{abstract}
Implementation of modern handling facilities contributes to the quality performance of each business subject. Nowadays, mechanization and automation of processes associated with the handling of shipments finds an important place especially under the conditions of the postal and logistics sector, which is growing due to ecommerce. The method of allocating large mechanization and automation, the performance and other characteristics significantly influence the realization of processing shipments in relation to the quality of service but also labour intensity and human performance. The paper deals with the issue of the appropriate location of the conveyor within the space available depot, as well as calculation of performance and technical parameters and multi-criteria evaluation for an appropriate choice of the conveyor. Such factors as energy performance, noise, safety at work, location and so on, were considered.
\end{abstract}

Keywords: conveyor, belt, sorting

\section{INTRODUCTION}

The current trends in the field of postal and logistical services indicate the necessity of automating activities related to the distribution of shipments. A major aspect of these trends is the growing volume of shipments originating in e-commerce. The increased demands on the manipulation with shipments of various nature (with a higher insurance value, fragile, bulky, and other individual demands) force the providers in the distribution process to effectively use not only the loading area of the transportation means, but also the time designated for sorting of shipments. Fulfilment of these goals is to a large extent to the use of sorting systems of various categories. That is the reason, why many authors are concerned with the implementation of appropriate sorting systems in postal and logistics enterprises $[1,2,5]$.
In the field of logistics and postal companies, depots and hubs use belt conveyors with telescopic superstructure for loading and offloading from the exterior, which are adjustable in height and length. Rolling conveyors are an indispensable part of sorting systems. Their construction can be adjusted to spatial conditions of the sorting or storage area, manipulation requirements of various height, angle, turns, speed, or weight of moved shipments.

With the help of scanning stations, an automated sorting system can route the shipments; it controls this process using various draw rods, swivel stands, and tilting parts of tracks. Using ICT this system has a lower requirement in terms of workload and also higher success-rate of correct sorting of items, which has a positive impact on customer satisfaction and good reputation of the company $[7,13]$. 


\section{ANALYSIS OF THE CURRENT STATE}

\section{Using conveyors for shipment sorting needs}

The distribution processes of providing postal or logistical service are carried out by providers in connection to the declared qualitative indicators of provided services, especially in the category of critically demanding shipments either in terms of delivery deadlines, or insurance sum. In the sorting centres, the activity is concentrated in two parts of the day, specifically the morning sorting and evening sorting of shipments.

The morning sorting of shipments and other follow-up activities are linked especially to the final stage of the transportation process, i.e. the delivery of shipments. Then, the shipments in the sorting centre will be delivered in a specified way within the attraction area of a given depot. The delivery method is determined by the request of the sender or the receiver. Currently, there are several possibilities. For the parcel market, the typical shipment delivery method is using couriers within a declared time, or by so-called rerouting of address and delivery time based on an individual receiver request. The customers" demands have generated many innovations in this area as well. The shipment can be delivered also using self-service devices, so-called packet boxes or pick-up stations.

The afternoon or evening sorting represents the processing of shipments (haulages), which were collected from senders during the day within the attraction area of given depot, or they have been received and designated for sorting from other attraction districts (in case a given depot is a central hub).

These are the shipments, which in most cases leave the depot in the evening after being sorted, and they are transported to the depot, in the district of which they will be delivered the next business day. In the case of international transportation, the cross-border shipment will be directed to a designated domestic central hub or an international hub, and in connection to the designated processing technology it will be redirected in the specified way to the destination country.

\section{Examination of positive and negative aspects in real environment}

The monitoring of activities and environment in the operation of a selected postal and logistical enterprise focused on collection and distribution of parcel and express shipments and providing logistics services provided many incentives to examine the work load, safety and efficiency of shipment handling using roller conveyors. It is a depot, which does not have a sorting system with automatic shipment routing at its disposal; instead, it uses only a simple roller track equipped with a scanning device and repeated scanning. The following negative aspects have been identified:

- constant speed, which is problematic in case of increased volume of shipments on the roller track and prevents continuous scanning or removal of shipments to individual directions there is a need to change the speed on the go

- missing side panels cause fall and subsequent damage of the shipment

- distance of rollers - while processing smaller shipments or shipments of non-standard shape, the used roller track is problematic due to occurring stoppage of shipments and their falling between the rollers. This situation requires a physical intervention of a person, thus creating a risk of damaging the content of the shipment.

- the conveyor is not finished - roller track without a driving end does not end with side panels, nor an option to redirect shipments that were not picked to another conveyor. Another important element is missing here, specifically a device scanning or detecting the volume of shipments accumulating at the end of the conveyor, which would signal this status, or could stop or slow down the whole conveyor.

- missing option of loading directly from the exterior during loading and offloading of shipments. The difficulty of manual labour is increasing, as well as required time for handling of shipments. A suitable solution would be the installation of a telescopic conveyor, or financially undemanding alternative, socalled scissor track. 


\section{GOAL AND METHODOLOGY}

The goal of the paper is to present the research results and solutions of implementing a handling device for the sorting centre providing postal and logistical services. The design of the solution is processed in the form of variant solutions in connection to basic requirements for the direction of shipment movement, type of conveyor, and placement of the conveyor. The mathematical formulas by Martínek (1993) and Marasová (2006) were used for the calculation and examination of usability and efficiency of individual solutions.

\section{SOLUTION PROPOSAL BASED ON SELECTED CRITERIA}

While selecting a new conveyor, it is necessary to also consider the method of its placement in spaces due to the shape of the conveyor and suitable conditions for loading, offloading, and handling of shipments. The considered variant solutions represent the use of a combination of a roller conveyor and a belt track of the conveyor.

The conveyor track will be located in the central part of the depot, which will allow to create sufficient space for handling of shipments, service personnel, as well as couriers.

\section{Calculating a driven roller conveyor}

We assume that the manipulation device is composed of individual segment, which will be mutually interconnected. A single segment is $4 \mathrm{~m}$ long.

1. We choose:

a) The speed in relation to the expected manual handling $\mathrm{v}=0.5 \mathrm{~m} \cdot \mathrm{s}^{-1}$

b) Number of shipments

$$
k=\frac{N .1}{3600 \cdot v}=\frac{1200.4}{3600 \cdot 0,5}=2.667 \doteq 3(\mathrm{pcs})
$$

The weight of the object (shipment) per one roll

$$
m=\frac{m_{p}}{k_{1}}=\frac{60}{8}=7.5(\mathrm{~kg})
$$

2. The total number of rollers on the track

$$
\mathrm{z}=\frac{1}{\mathrm{t}}=\frac{4}{0.8}=50 \mathrm{pcs}
$$

3. The power required for even movement

$$
\begin{aligned}
& P=\left\{\mathrm{n} \cdot \mathrm{k}_{1} \mathrm{~m} \cdot \mathrm{g}\left[\sin \beta+\cos \beta\left(\frac{\mathrm{e}+\mathrm{f} \cdot \mathrm{r}}{\mathrm{R}}+0.005\right)\right]+\right. \\
& \left.+\mathrm{m}_{\mathrm{v}} \cdot \mathrm{g} \frac{\mathrm{f} \cdot \mathrm{r}}{\mathrm{R}} \mathrm{Z}\right\} \cdot \frac{\mathrm{v}}{1000 \cdot \eta_{1}}=0.37458 \mathrm{~kW}
\end{aligned}
$$

4. The number of driving rollers $k_{p}$

$$
\begin{aligned}
& \text { m.g. } \mathrm{k}_{\mathrm{p}} \cdot \cos \beta \cdot \mu \geq \mathrm{m}_{\mathrm{p}} \cdot \mathrm{g} \cdot \sin \beta+\left(\mathrm{k}_{1}-\mathrm{k}_{\mathrm{p}}\right) \\
& {\left[\left(\frac{\mathrm{e}+\mathrm{f} \cdot \mathrm{r}}{\mathrm{R}}+0.005\right) \mathrm{m} \cdot \mathrm{g} \cdot \cos \beta+\mathrm{m}_{\mathrm{v}} \cdot \mathrm{g} \frac{\mathrm{f} \cdot \mathrm{r}}{\mathrm{R}}\right]}
\end{aligned}
$$

After adjustment $\mathrm{kp} \geq 1.378 \doteq 2$

5. Additional power if on item (shipment) stop

$$
\begin{aligned}
& \mathrm{P}_{1}=\mathrm{m} \cdot \mathrm{g} \cdot \mathrm{k}_{\mathrm{p}} \cos \beta \cdot \mu \frac{\mathrm{v}}{1000 \cdot \eta_{1}} \\
& \mathrm{P}_{1}=0.519 \mathrm{~kW}
\end{aligned}
$$

6. Overall performance

$$
\begin{aligned}
& \mathrm{P}_{\mathrm{c}}=\mathrm{P}+\mathrm{P}_{1} \\
& \mathrm{P}_{\mathrm{c}}=0.894 \mathrm{~kW}
\end{aligned}
$$

On the basis of market availability, considering availability and corresponding parameters, it is possible to select a low-vibration and low-rotation motor with a power of $1.1 \mathrm{~kW}$. The motor is powered at $230 \mathrm{~V}$ or $400 \mathrm{~V}$ with a frequency of $50 \mathrm{~Hz}$, weighing $22 \mathrm{~kg}$ and a production speed of $705 \mathrm{rpm}$.

Table 1. Basic parameters of the roller conveyor

\begin{tabular}{|l|c|}
\hline \multicolumn{1}{|c|}{ Parameter } & Value \\
\hline Width of the rollers & $\mathrm{B}=1 \mathrm{~m}$ \\
\hline Required transport performance & $\mathrm{N}=1200 \mathrm{pcs} \cdot \mathrm{h}^{-1}$ \\
\hline Maximum transport speed & $\mathrm{I}=4 \mathrm{~m}$ \\
\hline Track length & $\mathrm{D}=0.0795 \mathrm{~m}$ \\
\hline Diameter of the rollers & $\mathrm{m}_{\mathrm{v}}=8 \mathrm{~kg}$ \\
\hline $\begin{array}{l}\text { The weight of the rotating parts of the } \\
\text { rollers }\end{array}$ & $\mathrm{d}=0.0265 \mathrm{~m}$ \\
\hline Diameter of the pin in the rollers & $\mathrm{t}=0.08 \mathrm{~m}$ \\
\hline Pitch of rollers & $\mathrm{e}=0.0006 \mathrm{~m}$ \\
\hline The arm of the rolling friction & $\mathrm{f}=0.02$ \\
\hline Coefficient of rolling friction & $\mathrm{n}_{\mathrm{i}}=0.85$ \\
\hline Efficiency of gears & $\mathrm{u}=0.15$ \\
\hline $\begin{array}{l}\text { The coefficient of skid friction between } \\
\text { the rollers and the objects }\end{array}$ & $\beta=0^{\circ}$ \\
\hline Slope of conveyor track & $\mathrm{s}=0.004 \mathrm{~m}$ \\
\hline The thickness of the roller shell & $\mathrm{m}_{\mathrm{p}}=60 \mathrm{~kg}$ \\
\hline Weight of one item (shipment) & $\mathrm{k}_{1}=8$ \\
\hline $\begin{array}{l}\text { The number of rollers under the } \\
\text { shipment }\end{array}$ & \\
\hline
\end{tabular}




\section{Calculating a roller conveyor in a turn}

Identical input data as in the previous case was used for calculation. It is necessary to consider the new transportation distance. Alternating directions are exactly $1 \mathrm{~m}$ apart. The internal arc diameter is $0.5 \mathrm{~m}$ and the outer arc diameter is $1.5 \mathrm{~m}$. Using the difference of these values we calculated the mean diameter $\mathrm{r}=1 \mathrm{~m}$.

Circumference

$$
\begin{aligned}
& \mathrm{O}=2 \pi \mathrm{r}=2 \times 3.14 \times 1=6.28 \mathrm{~m} \\
& \mathrm{l}=\frac{\mathrm{O}}{2}=\frac{6,28}{2}=3.14 \mathrm{~m}
\end{aligned}
$$

The slope of the conveyor is $\delta=0^{\circ}$, since this is not movement of shipment on a sloped conveyor. Transportation distance: $1=3.14 \mathrm{~m}$

1. speed - due to assumed manual manipulation the chosen speed is $\mathrm{v}=0.5 \mathrm{~m} \cdot \mathrm{s}^{-1}$ number of shipments on the conveyor $k=2.09 \doteq 3$ pcs

2. weight of the object (shipments) per roller $\mathrm{m}=7.5 \mathrm{~kg}$

3. total number of rollers on the track $Z=39$ rollers

4. required power for even movement $\mathrm{P}=0.351 \mathrm{~kW}$

5. number of driving rollers $k_{p}$

Since this is a calculation of a conveyor in an arc, it is probable that a higher resistive force will be generated on a roller as the shipment moves from one roller to the next. Therefore, the friction coefficient was doubled for this calculation, $k_{p} \geq 5.598 \doteq 5$

During the operation it was that shipments of smaller sizes are transported as well. The conveyor drove all the rollers to avoid possible misalignment of these shipments on the conveyor. This means that the value $\mathrm{k}_{\mathrm{p}}=8$ was considered.

6. Additional power if one item stops $\mathrm{P}_{1}=0.519 \mathrm{~kW}$ 7. $\mathrm{P}_{\mathrm{c}}=0.87 \mathrm{~kW}$

\section{Calculation of belt conveyor for different lengths}

The first part of the conveyor was $4 \mathrm{~m}$ long, the second $24 \mathrm{~m}$, and the third returning part was $20 \mathrm{~m}$ long. The interconnection of the bridging belts in turns was implemented via a roller stool, since in this situation and in these directions it is not possible to use conveyor belts. The width of the belt was chosen based on the dimensions of distributed shipments. The business terms state the standard size of the bottom of the shipment as $70 \times 70 \mathrm{~cm}$. Practice also permits the situations where shipments of larger sizes are distributed. Therefore, we considered the belt width $\mathrm{B}=1 \mathrm{~m}$ to create a reserve.

\section{Example: Calculating $4 \mathrm{~m}$ long driven belt conveyor}

Slope of conveyor track $\beta=0^{\circ}$

1. speed - due to assumed manual manipulation the chosen speed is $\mathrm{v}=0.5 \mathrm{~m} \cdot \mathrm{s}^{-1}$

number of shipments on the conveyor

$$
k=2.67 \doteq 3
$$

Spacing of shipments $\mathrm{t}_{\mathrm{k}}=1.5 \mathrm{~m}$

Weight of one object (shipment) $\mathrm{m}_{\mathrm{dm}}=\mathrm{m}_{\mathrm{p}} \cdot \mathrm{k}=60 \times 3=180 \mathrm{~kg}$

2. The weight of the shipment per 1 meter of the conveyor length $\mathrm{m}_{1}=\frac{\mathrm{m}_{\mathrm{dm}}}{\mathrm{l}}=\frac{100}{4}=45 \mathrm{~kg}$

3. The choice of belts and rolls at the specified belt width $\mathrm{B}=1 \mathrm{~m}$

A belt conveyor which is resistant to mineral oils and fats, and is suitable for transportation of packaged food, wood, and plastic shipments and other small items, was selected. The belt strength is $18 \mathrm{~N} / \mathrm{mm}$. It is possible to use it in operating conditions from $-10^{\circ} \mathrm{C}$ to $+80^{\circ} \mathrm{C}$. The weight of one meter at width of $1000 \mathrm{~mm}$ is $\mathrm{m}_{2}=4.6 \mathrm{~kg}$. The thickness of the belt is $3.8 \mathrm{~mm}$. The minimum diameter of the driving drum must be 120 $\mathrm{mm}$. From a safety point of view it is suitable to consider a $200 \mathrm{~mm}$ diameter of the driving drum.

4. Determining the main drag resistance

a) upper conveyor branch:

$$
\mu=\mu_{1} \cdot k_{1}=0.02 .1 .07=0.0214
$$

where: $\mu-$ global friction coefficient

$\mu_{1}$ - the friction coefficient at $20^{\circ} \mathrm{C}$ is in the range of $0.018-0.027$, depending on the quality of production and operating conditions $\mu_{1}=0.02$

$\mathrm{k}_{1}$ - the coefficient respecting the effect of temperature, $\mathrm{k}_{1}$ has a value of 1.07 . This

Table 2. Input values of the conveyor belt

\begin{tabular}{|l|c|}
\hline \multicolumn{1}{|c|}{ Parameter } & Value \\
\hline Required transport performance & $\mathrm{N}=1200 \mathrm{pcs} \cdot \mathrm{h}^{-1}$ \\
\hline Maximum transport speed & $\mathrm{v}=0,5 \mathrm{~m} \cdot \mathrm{s}^{-1}$ \\
\hline Track length & $\mathrm{I}=4 \mathrm{~m}$ \\
\hline Pitch of rollers of upper stool & $\mathrm{t}_{\mathrm{h}}=0,25 \mathrm{~m}$ \\
\hline Pitch of rollers of lower stool & $\mathrm{t}_{\mathrm{d}}=1 \mathrm{~m}$ \\
\hline Slope of conveyor track & $\beta=0^{\circ}$ \\
\hline Weight of one item (shipment) & $\mathrm{m}_{\mathrm{p}}=60 \mathrm{~kg}$ \\
\hline
\end{tabular}


value was chosen due to decrease of temperature in the sorting centre in the winter season to $0^{\circ} \mathrm{C}$

- $\mathrm{m}_{\mathrm{rh}}$ - the weight of the rotating rollers in the upper conveyor branch corresponding to a length of $1 \mathrm{~m}$

- $\mathrm{m}_{\mathrm{rv}}$ - weight of rotating parts of one roller in the upper branch $(4 \mathrm{~kg})$

- $\mathrm{n}_{\mathrm{h}}$ - number of rollers in the upper part of the stool corresponding to a length of $1 \mathrm{~m}$ (4 rollers)

$$
\begin{aligned}
& m_{r h}=m_{r v} \cdot n_{h}(\mathrm{~kg}) \\
& m_{r h}=16 \mathrm{~kg} \\
& F_{H h}=\mu .1 . \mathrm{g}\left[\left(m_{1}+m\right) \cos \delta+m_{r h}\right](\mathrm{N}) \\
& F_{H h}=0.0214 x 4 x 9.81[(45+4.6) \cos 0+16]= \\
& =55.08 \mathrm{~N}
\end{aligned}
$$

b) lower conveyor branch

- $\mathrm{m}_{\mathrm{rd}}$ - weight of rotating parts of the rollers of the lower branch $(4 \mathrm{~kg})$

The rollers used in the lower branch were identical to those used in the upper branch; the pitch of the lower stools rollers changed $\mathrm{t}_{\mathrm{d}}=1 \mathrm{~m}$

$$
\begin{aligned}
& m_{r d}=\frac{m_{r d} \cdot n_{d}}{t_{d}}(\mathrm{~kg}) \\
& m_{r d}=4 \mathrm{~kg} \\
& F_{H d}=\mu . . l \cdot \mathrm{g}\left(m_{2} \cos \delta+m_{r d}\right)(\mathrm{N}) \\
& F_{H d}=0.0214 x 4 x 9.81(4.6 \cos 0+4)=7.22 \mathrm{~N}
\end{aligned}
$$

5. Determining secondary resistances

The resistance due to bending of the belt over the drums is predicted to be $100 \mathrm{~N}$ per single drum. $F_{v 2}=200 \mathrm{~N}$

Similarly, the resistance due to the pin friction of drums not driven is estimated to $100 \mathrm{~N}$ per single drum.

$F_{v 3}=100 \mathrm{~N}$

6. Determining additional resistances

Resistance to overcoming the conveyor height separately for the upper and lower branch

$$
\begin{aligned}
& \mathrm{F}_{\mathrm{p} 1 \mathrm{~h}}=\left(\mathrm{m}_{1}+\mathrm{m}_{2}\right) \mathrm{g} . \mathrm{H} \\
& \mathrm{F}_{\mathrm{p} 1 \mathrm{~h}}=(45+4.6) 9.8 \times 0=0 \mathrm{~N} \\
& \mathrm{~F}_{\mathrm{p} 1 \mathrm{~d}}=\mathrm{m}_{2} \cdot \mathrm{g} \cdot \mathrm{H} \quad(\mathrm{N}) \\
& \mathrm{F}_{\mathrm{pld}}=4.6 \times 9.81 \times 0=0 \mathrm{~N}
\end{aligned}
$$

Side line resistance - prevents falling of the shipment from the conveyor

$$
\begin{aligned}
& \mathrm{F}_{\mathrm{p} 2 \mathrm{~h}}=\mu_{2} \frac{\mathrm{m}_{1} \mathrm{l}_{\mathrm{B}} \mathrm{g}}{2 \mathrm{~b}_{\mathrm{v}}}(\mathrm{N}) \\
& \mathrm{F}_{\mathrm{p} 2 \mathrm{~h}}=0.6 \frac{45.4 .9 .81}{2.0 .7}=753.77 \mathrm{~N}
\end{aligned}
$$

- $\mu_{2}$ - coefficient of shear friction between the shipment and side line (0.6)

- $1_{B}$ - length of the side line $(4 \mathrm{~m})$
- $b_{v}$ - light width designated by the width of the shipment (0.7)

7. Maximum belt thrust - at the point where the belt is going over the driving drum

$$
\mathrm{F}_{1}=\frac{\mathrm{Z}}{2}+\mathrm{F}_{\mathrm{Hh}}+\mathrm{F}_{\mathrm{v} 2}+\mathrm{F}_{\mathrm{p} 1 \mathrm{~h}}+\mathrm{F}_{\mathrm{p} 2 \mathrm{~h}}
$$

Belt thrust on the moving side of the drive drum

$$
\mathrm{F}_{2}=\frac{\mathrm{Z}}{2}-\mathrm{F}_{\mathrm{Hd}}+\mathrm{F}_{\mathrm{p} 1 \mathrm{~d}}
$$

Perimeter force on the driving drum

$$
\begin{aligned}
& \mathrm{F}=\mathrm{F}_{1}-\mathrm{F}_{2}=\mathrm{F}_{\mathrm{Hh}}+\mathrm{F}_{\mathrm{Hd}}+\mathrm{F}_{\mathrm{v} 2}+\mathrm{F}_{\mathrm{v} 3}+ \\
& +\mathrm{F}_{\mathrm{p} 1 \mathrm{~h}}-\mathrm{F}_{\mathrm{p} 1 \mathrm{~d}}+\mathrm{F}_{\mathrm{p} 2 \mathrm{~h}}(\mathrm{~N}) \\
& \mathrm{F}=\mathrm{F}_{1}-\mathrm{F}_{2}=55.08+7.22+100+200+0-0+756.77= \\
& =1119.77 \mathrm{~N}
\end{aligned}
$$

8. Required power on the drive shaft of the drum

$$
\begin{aligned}
& \mathrm{p}=\frac{\mathrm{F} \cdot \mathrm{v}}{\eta}(\mathrm{kW}) \\
& \mathrm{p}=\frac{1119.77 .0 .5}{0,6}=0.933 \mathrm{~kW}
\end{aligned}
$$

$\eta$ - efficiency of gears $(0,6)$

9. Tension size (from relationship for $\mathrm{F}_{2}$ )

$$
\mathrm{Z}=2\left(\mathrm{~F}_{2}+\mathrm{F}_{\mathrm{Hd}}-\mathrm{F}_{\mathrm{p} 1 \mathrm{~d}}\right)
$$

Force $\mathrm{F}_{2}$ can be expressed depending on $\mathrm{F}$

$$
\begin{aligned}
& \mathrm{F}_{2}=\mathrm{F} \frac{1}{\mathrm{e}^{\mathrm{f} \cdot \alpha}-1} \\
& \mathrm{~F}_{2}=1119.77 \frac{1}{2.566-1}=715.53 \mathrm{~N}
\end{aligned}
$$

- $\mathrm{f}$ - friction coefficient between the belt and the drum ( $\mathrm{f}=0.3)$

- $\alpha$-curvature in the angle $\left(\alpha=180^{\circ}\right)$

Technical literature mentions a value of $\mathrm{e}^{\mathrm{f} . \alpha}=2.566$

The tension force is recommended to be increased by $5-10 \%$. Then the tension force is $751.30 \mathrm{~N}$.

10.Checking the strength of the traction device Maximum belt tension after correction of tension force $Z=2(751.30+7.22-0)=$ $1517.04 \mathrm{~N}$

$$
\begin{aligned}
& F_{1}=\frac{Z}{2}+F_{H h}+F_{v 2}+F_{v 3}+F_{p 1 h}+F_{p 2 h}(N) \\
& F_{1}=\frac{1574.04}{2}+55.08+200+100+0+756.77= \\
& =1870.37 \mathrm{~N}
\end{aligned}
$$

The allowed belt tension is $18 \mathrm{~N}$ for $1 \mathrm{~mm}$ of width, this means that the allowed tension force for a $1000 \mathrm{~mm}$ wide belt is $\mathrm{F}_{\mathrm{D}}=18000 \mathrm{~N}$.

$\mathrm{F}_{1} \leq \mathrm{F}_{\mathrm{D}}$ belt is compliant tension-wise with the 9-fold safety. 


\section{Selecting a belt conveyor}

A whole range of decision making methods can be used to select a suitable solution of a belt conveyor based on the available information for individual variant solutions. The method of paired comparison seems to be suitable and relatively simple, belonging to a group of methods of multi-criterion decision making. The decision making is based on the following criteria:
A: energy demand
B: investment difficulty
C: safety
D: noise level in the operation
E: layout and direction of conveyors

\section{Variant solutions}

- V1 - belt conveyor, turning direction to the right, placement 6 meters from the left side of the depot

- V2 - belt conveyor, turning direction to the right, placement 6 meters from the left side of the depot

- V3 - roller conveyor, turning direction to the left, placement in the central part of the depot

- V4 - belt conveyor, turning direction to the left, placement in the central part of the depot

The method of paired comparison identifies the preferential relationships of a pair of criteria. The task is to determine the number of preferences for each criterion in relation to all other

Table 3. Calculating of belt conveyor for different lengths

\begin{tabular}{|c|c|c|c|}
\hline \multirow{2}{*}{ Parameter/indicator } & \multicolumn{3}{|c|}{ Length of conveyor } \\
\hline & $\mathrm{I}=4 \mathrm{~m}$ & $\mathrm{I}=20 \mathrm{~m}$ & $\mathrm{I}=24 \mathrm{~m}$ \\
\hline Slope of conveyor & $\delta=0^{\circ}$ & $\delta=0^{\circ}$ & $\delta=0^{\circ}$ \\
\hline k.- number of shipments on the conveyor (pcs) & 3 & 14 & 16 \\
\hline$t_{k} \cdot-$ Spacing of shipments $(\mathrm{m})$ & 1.5 & 1.5 & 1.5 \\
\hline$m_{d m} .-$ The weight of the transported items on the conveyor $(\mathrm{kg})$ & 180 & 840 & 960 \\
\hline$m_{1} .-$ The weight of the shipment per $1 \mathrm{~m}$ of the conveyor length $(\mathrm{kg})$ & 45 & 42 & 40 \\
\hline$m_{2} .-$ Belt weight per 1 meter width $(\mathrm{kg})$ & 4.6 & 4.6 & 4.6 \\
\hline \multicolumn{4}{|l|}{ The main drag resistance } \\
\hline$\mu .-$ global friction coefficient & 0.0214 & 0.0214 & 0.0214 \\
\hline$\mu_{1} .-$ friction coefficient & 0.02 & 0.02 & 0.02 \\
\hline$k_{1} .-$ the coefficient respecting the effect of temperature & 1.07 & 1.07 & 1.07 \\
\hline $\begin{array}{l}m_{r} .- \text { the weight of the rotating rollers in the upper conveyor branch corresponding to a } \\
\text { length of } 1 \mathrm{~m}(\mathrm{~kg})\end{array}$ & 16 & 16 & 16 \\
\hline$m_{n} .-$ weight of rotating parts of one roller in the upper branch $(\mathrm{kg})$ & 4 & 4 & 4 \\
\hline$n_{h}$.- number of rollers in the upper part of the stool corresponding to a length of $1 \mathrm{~m}$ (pcs) & 4 & 4 & 4 \\
\hline$F_{H h} .-$ The main resistance - upper branch $(\mathrm{N})$ & 55.08 & 262.84 & 305.32 \\
\hline$m_{r d} .-$ weight of rotating parts of the rollers of the lower branch $(\mathrm{kg})$ & 4 & 4 & 4 \\
\hline$F_{H d}-$ The main resistance - lower branch $(\mathrm{N})$ & 7.22 & 36.10 & 43.33 \\
\hline \multicolumn{4}{|l|}{ Determining secondary resistances } \\
\hline$F_{v 2} \cdot-$ Resistance due to belt bending $(\mathrm{N})$ & 200 & 200 & 200 \\
\hline$F_{v 3}-$ Resistance due to pinhole friction $(\mathrm{N})$ & 100 & 100 & 100 \\
\hline \multicolumn{4}{|l|}{ Determining additional resistances } \\
\hline$F_{p \nmid h} .-$ Resistance to overcoming conveyor height - upper branch $(\mathrm{N})$ & 0 & 0 & 0 \\
\hline$F_{p 1 d} .-$ Resistance to overcoming conveyor height - lower branch $(\mathrm{N})$ & 0 & 0 & 0 \\
\hline$F_{p 2 h} .-$ Side line resistance $(\mathrm{N})$ & 753.77 & 3531.60 & 4036.12 \\
\hline Maximum belt thrust $F$.- Perimeter force on the driving drum (N) & 1119.77 & 4130.54 & 4684.77 \\
\hline Power on the drive shaft $P-(\mathrm{kW})$ & 0.933 & 3.442 & 3903.97 \\
\hline $\mathrm{F}_{2} .-$ Belt thrust on the moving side of the drive drum $(\mathrm{N})$ & 715.53 & 2639.41 & 2993.57 \\
\hline Tension force.- adjusted value $(\mathrm{N})$ & 751.30 & 2771.38 & 3143.25 \\
\hline \multicolumn{4}{|l|}{ Checking the strength of the traction device } \\
\hline Z.- Maximum belt tension after correction of tension force & 1517.04 & 5614.96 & 6373.16 \\
\hline$F_{1} .-$ Maximum belt thrust - at the point where the belt is going over the driving drum $(\mathrm{N})$ & 1870.37 & 6901.92 & 7828.02 \\
\hline
\end{tabular}


criteria of the set. The preference determination is as follows: in the upper right part of the table (upper triangle matrix) the evaluator determines for each pair of criteria, whether the criterion in the row is preferred to the criterion in the column. If yes, then it writes a value in the corresponding field, otherwise it writes 0 . While evaluating this table, the number of preferences was determined for each criterion, which equals to the sum of its preferences in the row and the column of this criterion. In the case of the same number of prefer- ences for two (or more) criteria, it is necessary to consider the direction of preference of these pairs of criteria. The ranking of given criterion in the set of criteria was determined based on the number of preferences. If a criterion achieves a 0 value, it is necessary to add +1 to each criterion (see Table 4 ).

Calculating partial benefits of each variant through paired comparison and their conversion to standard values based on each criterion is identical to the previous procedure. Rating a variant can have a value of 0 .

Table 4. Determining preferencial weights of the criterions by the method of paired comparison

\begin{tabular}{|c|c|c|c|c|c|c|c|c|}
\hline Criterion & A & B & C & D & E & $\begin{array}{c}\text { Number of } \\
\text { preferences }\end{array}$ & $\begin{array}{c}\text { Recalculated number } \\
\text { of preferences }\end{array}$ & $\begin{array}{c}\text { Standardized } \\
\text { weights } \alpha\end{array}$ \\
\hline A & - & 1 & 0 & 0 & 0 & 1 & 2 & 0.1333 \\
\hline B & & - & 0 & 0 & 0 & 0 & 1 & 0.0667 \\
\hline C & & & - & 1 & 1 & 4 & 5 & 0.3333 \\
\hline D & & & & - & 1 & 3 & 4 & 0.2667 \\
\hline E & & & & & - & 2 & 3 & 0.2000 \\
\hline Sum & & & & & & & 15 & 1 \\
\hline
\end{tabular}

Table 5. Calculating partial benefits of each variant through paired comparison

\begin{tabular}{|c|c|c|c|c|c|c|}
\hline Matrix A & $V_{1}$ & $\mathrm{~V}_{2}$ & $\mathrm{~V}_{3}$ & $\mathrm{~V}_{4}$ & Number of preferences & Usefulness $\mathrm{u}_{\mathrm{i}}$ \\
\hline $\mathrm{V}_{1}$ & - & 0 & 1 & 0 & 1 & 0.1667 \\
\hline $\mathrm{V}_{2}$ & & - & 1 & 0 & 2 & 0.3333 \\
\hline $\mathrm{V}_{3}$ & & & - & 0 & 0 & 0 \\
\hline $\mathrm{V}_{4}$ & & & & - & 3 & 0.5000 \\
\hline Sum & & & & & 6 & 1 \\
\hline Matrix B & $V_{1}$ & $\mathrm{~V}_{2}$ & $\mathrm{~V}_{3}$ & $\mathrm{~V}_{4}$ & Number of preferences & Usefulness $u_{i}$ \\
\hline $\mathrm{V}_{1}$ & - & 0 & 0 & 0 & 0 & 0 \\
\hline$V_{2}$ & & - & 1 & 1 & 3 & 0.5000 \\
\hline$V_{3}$ & & & - & 0 & 1 & 0.1667 \\
\hline $\mathrm{V}_{4}$ & & & & - & 2 & 0.3333 \\
\hline Sum & & & & & 6 & 1 \\
\hline Matrix C & $\mathrm{V}_{1}$ & $\mathrm{~V}_{2}$ & $\mathrm{~V}_{3}$ & $\mathrm{~V}_{4}$ & Number of preferences & Usefulness $\mathrm{u}_{\mathrm{i}}$ \\
\hline$V_{1}$ & - & 0 & 1 & 0 & 1 & 0.1667 \\
\hline$V_{2}$ & - & - & 1 & 0 & 2 & 0.3333 \\
\hline$V_{3}$ & - & - & - & 0 & 0 & 0 \\
\hline $\mathrm{V}_{4}$ & - & - & - & - & 3 & 0.5000 \\
\hline Sum & & & & & 6 & 1 \\
\hline Matrix D & $\mathrm{V}_{1}$ & $\mathrm{~V}_{2}$ & $\mathrm{~V}_{3}$ & $\mathrm{~V}_{4}$ & Number of preferences & Usefulness $u_{i}$ \\
\hline$V_{1}$ & - & 0 & 1 & 0 & 1 & 0.1667 \\
\hline$V_{2}$ & - & - & 1 & 1 & 3 & 0.5000 \\
\hline$V_{3}$ & - & - & - & 0 & 0 & 0 \\
\hline $\mathrm{V}_{4}$ & - & - & - & - & 2 & 0.3333 \\
\hline Sum & & & & & 6 & 1 \\
\hline Matrix E & $V_{1}$ & $\mathrm{~V}_{2}$ & $\mathrm{~V}_{3}$ & $\mathrm{~V}_{4}$ & Number of preferences & Usefulness $u_{i}$ \\
\hline$V_{1}$ & - & 1 & 1 & 1 & 3 & 0.5000 \\
\hline$V_{2}$ & - & - & 1 & 0 & 1 & 0.1667 \\
\hline$V_{3}$ & - & - & - & 0 & 0 & 0 \\
\hline$V_{4}$ & - & - & - & - & 2 & 0.3333 \\
\hline Sum & & & & & 6 & 1 \\
\hline
\end{tabular}


Table 6. Calculating the so-called overall usefulness for selecting the most suitable variant

\begin{tabular}{|c|c|c|c|c|c|c|c|c|c|}
\hline \multirow{2}{*}{ Criterion } & Variants & \multicolumn{2}{|c|}{$\mathrm{V}_{1}$} & \multicolumn{2}{|c|}{$\mathrm{V}_{2}$} & \multicolumn{2}{c|}{$\mathrm{V}_{3}$} & $\mathrm{~V}_{4}$ \\
\cline { 2 - 10 } & $\mathrm{\alpha}_{1}$ & $\mathrm{u}_{\mathrm{i}}$ & $\mathrm{\alpha}_{1} \cdot \mathrm{u}_{\mathrm{i}}$ & $\mathrm{u}_{\mathrm{i}}$ & $\mathrm{\alpha}_{1} \cdot \mathrm{u}_{\mathrm{i}}$ & $\mathrm{u}_{\mathrm{i}}$ & $\mathrm{\alpha}_{1} \cdot \mathrm{u}_{\mathrm{i}}$ & $\mathrm{u}_{\mathrm{i}}$ & $\mathrm{\alpha}_{1} \cdot \mathrm{u}_{\mathrm{i}}$ \\
\hline $\mathrm{A}$ & 0.1333 & 0.1667 & 0.0222 & 0.3333 & 0.0444 & 0 & 0 & 0.5000 & 0.0666 \\
\hline $\mathrm{B}$ & 0.0667 & 0 & 0 & 0.5000 & 0.0334 & 0.1667 & 0.0111 & 0.3333 & 0.0222 \\
\hline $\mathrm{C}$ & 0.3333 & 0.1667 & 0.0556 & 0.3333 & 0.1111 & 0 & 0 & 0.5000 & 0.1666 \\
\hline $\mathrm{D}$ & 0.2667 & 0.1667 & 0.0445 & 0.5000 & 0.1334 & 0 & 0 & 0.3333 & 0.0889 \\
\hline $\mathrm{E}$ & 0.2000 & 0.5000 & 0.1000 & 0.1667 & 0.0334 & 0 & 0 & 0.3333 & 0.0667 \\
\hline & 1 & - & 0.2223 & - & 0.3557 & - & 0.0111 & - & 0.4110 \\
\hline
\end{tabular}

Calculating the so-called overallusefulnessand selecting the most suitable variant. The selection will be implemented as a maximization function.

Variant V4, i.e. the belt conveyor turning left appears to be fitting based on multicriterial assessment. Its placement is most suitable, it offers similar conditions for all couriers in terms of processing received shipments as well as preparation for delivery. Appropriate conditions are also created for the afternoon sorting, where suitable space is created on the right side of the depot for cage containers and other necessary handling and transportation units.

\section{CONCLUSION}

The efficiency of the distribution process for providers of logistic and postal services is an important attribute of their efforts. Constant improvement is also motivated by high competitive pressure and customer's demands. Innovations in processes are an important requirement to meet the declared quality as well as the efficiency of the process itself. If it is not possible to implement large investment project in the operation focused on the implementation of modern automatic sorting systems, there is always room for projects of a smaller investment scale in the form of modernizing existing handling and sorting systems. The paper points out the possibilities of considering suitable innovation of the sorting centre, taking into account technical, technologi$\mathrm{cal}$, and operational aspects. Thus, the method of paired comparison was chosen to select a suitable variant, which belongs in the theory of multicriterial decision-making.

\section{Acknowledgement}

VEGA 1/0721/15 - Research on the impact of postal services and telecommunication convergence on regulatory approaches in the postal sector

\section{REFERENCES}

1. Andrejiova, M., Grincova, A., Marasova, D.: Measurement and simulation of impact wear damage to industrial conveyor belts. Wear. Engineering: Mechanics of Materials. Vol. 368-369, 2016, 400-407.

2. Briskorn, Dirk; Emde, Simon; Boysen, Nils: Scheduling shipments in closed-loop sortation conveyors. Journal of Scheduling. 2017. 20(1). 25-42, DOI: $10.1007 / \mathrm{s} 10951-016-0498-5$.

3. Conradi, Alexander; de Beauregard, Dominique Melot; Benthaus, Burkhard; et al.: Approach for a Demand Compliant Choice of Induction Machines Used in Roller Conveyors. IEEE Conference: 20th International Conference on Electrical Machines (ICEM) Location: Marseille, FRANCE Date: SEP 02-05, 2012. pp. 1199-1205.

4. Droździel, P., Komsta, H., Krzywonos L.: An analysis of the relationships among selected operating and maintenance parameters of vehicles used in a transportation company. Transport Problems 2011, 4(6), 93.

5. Esoso Aghor, A., Simeon, A.P.: Model design and simulation of automatic sorting machine using proximity sensor. Engineering Science and Technology, an International Journal 2016, 19(3), 1452-1456, DOI: 10.1016/j.jestch.2016.04.007

6. He, D., Pang, Y., Lodewijks, G.: Speed control of belt conveyors during transient operation. In. Powder Technology. Section of Transport Engineering and Logistics, Delft University of Technology, Mekelweg 2, Delft, Netherlands. 2016. Vol. 301, pp. 622-631

7. Kolarovszki, P.; Tengler, J.: Practical research in field of automatic identification in automotive. In: Conference: Carpathian Logistics Congress (CLC) 2015. Location: Jesenik, Czech Republic. Nov. 04-06, 2015. TANGER Ltd. pp. 92-97. Published: 2016.

8. Marasová, D. et al.: Pásová doprava. Košice. PONT s.r.o., 2006. pp. 280.

9. Martínek, P.: Transportní zařízení. Ostrava: Ediční středisko VŠB v Ostravě, 1993, pp. 112.

10. McGuire, P. M,: Conveyors: Application, Selection, and Integration (Industrial Innovation Series). CRC Press, 2009.

11. Straka, M.: Logistika distribúcie: Ako efektívne 
dostat' výrobok na trh. Vydavatel'stvo: Epos, 2013.

12. Tho, TP., Thinh, NT.: Design and development of the sorting system based on robot. In: 5th International Conference on Control Automation and Systems. 2015, pp.1639-1644.
13. Vaculik, J., Tengler, J., Maslak, O.: How can new technologies to improve the delivery process. In: Conference Carpathian Logistics Congress (CLC 2013) Cracow, Poland, Dec. 09-11, 2013, pp. 236-242, Published: 2014. 